\title{
Introduction: Gender, Cultural Constructions and Representations in the Gulf
}

The ways in which gender and identity are both constructed and represented in the Gulf is an important and underrepresented area of academic inquiry. The essays in this special issue address a gap within the literature by analyzing and interrogating the sociocultural production of gender and identity. The authors of each essay seek to unpack the social, political, and economic structures and discourses that underpin gender identity construction in the Gulf, thus providing a framework from which to recognize the structures of power and the dominant ideologies that operate locally, nationally, regionally, and internationally. In addition, the issue explores how gender and identity intersect within the Gulf to produce distinct modes of cultural representation, both tangible and intangible. The editors and authors are particularly interested in exploring how both masculinity and femininity are constructed and represented in the Gulf region. The discussion of both masculine and feminine constructions and representations is important as it recognizes that these categories are not necessarily discrete but are interconnected and interrelated. It is therefore essential that debates around gender and identity in the Gulf are framed within discussions that give voice to both masculine and feminine cultural constructions and representations.

In "The Apocalyptic Hijab: Emirati Mediations of Pious Fashion and Conflict Talk," Ahmed Yaqoub AlMaazmi examines an Emirati animated sitcom, Shaabiat Al-Cartoon ( $S A C$ ), in order to understand the idiosyncratic concerns of what represents the quintessential characteristics of Emiratis in relation to clothing and language. Emirati popular culture - as mediated in animated sitcoms - is an integral part of the public discourse and imagination of gendered pious fashion and conflict talk, and $S A C$ is one of the earliest and most successful Emirati animated sitcoms in its portrayal of the tapestry of the United Arab Emirates' (UAE) ethnic, racial, and linguistic diversity. Through his analysis of this show, AlMaazmi suggests that the comic representation of day-to-day topics is used here as part of the process of reproducing Emirati group recognizability, thus consolidating their social citizenship. Depending on the episode, it subtly challenges, reproduces, or selectively furthers and complicates social personas in Emirati society. One of the significant recurrent 
themes in the show are fashion and gendered conflict talk. Of particular interest for the topic of this special issue, AlMaazmi's analysis specifically contributes to discussions of politics of piety and gendered conflict talk by analyzing the strategic illustration of UAE's female fashion sense and use of the linguistic features that move verbal dueling to verbal attack. His article demonstrates how the producers of an episode of $S A C$, through semiotic cues, attempt to reflect and shape Emirati sociocultural values on pious gendered clothing and perceptions of modernity.

Elizabeth Derderian, in her contribution, "Engendering Change: Charting a History of the Emirates through Women Artists," explores the intersection of gender, identity, and art in the UAE by charting the work of six female artists based in the UAE between 1980 and 2017. A pioneering generation of artists began making art in the 1980s in the UAE, which was then a newly formed nation. This generation included very few women artists; however, in subsequent years, the gendered trend amongst artists in the UAE reversed, and now female artists dominate the scene in the UAE. In her article, Derderian explores the political, economic, and cultural changes leading to the rise of arts in the UAE and the gendered shift from largely male to largely female cultural producers that occurred in the mid-20oos. The work of these six artists offers a productive lens through which to examine questions of national representation and national pride, and the roles that women play in producing the nation as civilized and cultured, especially women who reside in the country but are not citizens. By exploring how and where women artists could receive an arts education, and in which language, Derderian also charts changing centers of knowledge production for the Emirati community. In a related vein, her article addresses rapid demographic and infrastructural change, particularly as it has affected artists' abilities to have a studio, produce work, and exhibit it, but also the ways that these shifts drive the concepts behind the work of many UAE-based artists.

The article "From Invisible to Actualized: Imagery and Identity in Photos of Women in the Gulf," by Marjorie Kelly and Sara Al-Ajmi, begins with a summary of the history of photography of women in the Middle East, noting that a very small number of photos exist of women from the Gulf until recent times. Since women in the Gulf have been subject to the same stereotypes as women in other parts of the Arab world, the summary is necessary to understand what females behind and in front of the camera are seeking to redress. Kelly and Al-Ajmi note that, chronologically, women in the region have been invisible, eroticized, and exoticized in Orientalist photography, then appeared in family portraits as both the repository of cultural values and the new, modern woman 
as of the 1920s. Their analysis expands, however, to consider the reaction of contemporary female photographers to the perception of Gulf women as jobless, nameless, faceless, and voiceless; this analysis is presented through examples of art photography as well as photos used for political commentary. Through a discussion of the public image of Sheikha Moza of Qatar in terms of her astute use of visual communication by photograph, as well as an evaluation of Gulf females who take, send, and view selfies, the article addresses three aspects of photography - as art, as photojournalism, and as private communication that collectively construct visual representations of Gulf women's identity.

Ayisha Khansaheb uses the lens of food cooking and food-based rituals to examine the dramatic alteration of women's roles in the Emirati family in "Exploring the Nation: Gender, Identity, and Cuisine in the UAE." Traditionally, a woman's role was as the primary food producer and cook at the center of family life. By contrast, Khansaheb argues that, in recent decades, women have become commodity consumers and household managers, supervising foreign staff preparing meals in Emirati homes. The rapid change from subsistencelevel provision to global excess has deprived a younger generation of women of the culinary skills and cultural knowledge of their foremothers. In an effort to capture this significant moment of cultural transition, Khansaheb documents the rich culinary heritage, traditions, and food practices of the region in the words of the women who produced and prepared these foods, thus foregrounding their means of identity making, power, and cultural knowledge. Her research engages with collective and individual memory, nostalgia, and the desire among older Emirati women to preserve the skills and embodied forms of knowledge that may otherwise disappear or, perhaps even worse, become little more than clichéd, shallow heritage displays divorced from the meaningful experiences and lives of women themselves. Khansaheb uses oral histories of Emirati women to examine an alternative way of approaching nation building and identity formation in terms rarely considered in official histories. As a result of her analysis, she argues that the reductivist and essentializing public portrayals of the "ideal traditional Emirati woman" are challenged by the diverse, multifaceted, and engaged narratives of senior Emirati women who have lived through the fast-paced changes that have taken place in the Gulf over the last seventy years.

Heritage sites and studies of the pearling industry in Arab Gulf nations focus on men who labored as merchants, boat captains, and pearl divers. In "Beyond 'Man' vs. Nature: Pearling and the Construction of Gender, Generation, and Heritage in Bahrain," John Thabiti Willis argues that these sites represent merchants as having reaped the greatest returns and divers as having endured the 
greatest hardships over the history of the industry. In this standard narrative, nature emerges as the main adversary of divers. However, Willis reveals that British records from the 1930s (shortly after the collapse of the global market for Gulf pearls) not only document the tribulations that divers reported; they also depict human agency - instead of nature, chance, or divine intervention as the main source of misfortune for divers. These findings trouble "official" representations of pearl diving, particularly the treatment of the divers, at heritage sites. In his article, Willis presents a case study of the island kingdom and nation of Bahrain - once a premier exporter of pearls in the Gulf and recently home to a World Heritage Site devoted to pearling - analyzing two types of sources pertaining to Bahrain, heritage sites and British Political Agency records. He critically examines the ways in which these sites portray the gender and identity of divers as cultural constructions and representations of heritage discourses. He argues that, in order to understand the ways in which gender and identity are culturally constructed through the sites in Bahrain, the reader should compare the two narratives - one that depicts nature as the chief danger to pearl divers, and another that depicts human agency as a threat.

In these five articles, the authors explore both historical and contemporary circumstances that shape the construction of gender identity in the Gulf. They do so in ways that encourage new consideration of overlooked narratives, as well as a deeper reflection on the ways in which social, political, and religious contexts affect, and are affected by, understandings of Khalijī gender identity on the part of both locals and outsiders. As such, they make an important contribution to the field of gender studies in the Gulf region.

\author{
Sarina Wakefield \\ School of Museum Studies, University of Leicester, Leicester, UK \\ sarina.wakefield@leicester.ac.uk
}

Sabrina DeTurk

College of Arts and Creative Enterprises, Zayed University, Dubai, UAE sabrina.deturk@zu.ac.ae 